\title{
Geochemistry, Mineral Chemistry and Thermobarometry of Boneh-Shorou Amphibolites in Gelmandeh Massive (Saghand-Central Iran)
}

\author{
Arash Gourabjeiri-Pour1, Soraya Heuss-Aßbichler², Mohsen Mobasheri ${ }^{3 *}$, \\ Parivash Mahdavi ${ }^{4}$ \\ ${ }^{1}$ Department of Geology, Faculty of Science, Miyane Branch, Islamic Azad University, Miyane, Iran \\ ${ }^{2}$ Department of Earth and Environmental Sciences, Section for Mineralogy, Petrology and Geochemistry, \\ Ludwig-Maximilians University, Muenchen, Germany \\ ${ }^{3}$ Department of Petrology and Economic Geology, School of Geosciences, Shahrood University of Technology, \\ Shahrood, Iran \\ ${ }^{4}$ Department of Geology, Faculty of Science, Science and Research Branch, Islamic Azad University, Tehran, \\ Iran \\ Email: arash_firm@yahoo.com, soraya@min.uni-muenchen.de, “mobasheri.mohsen@shahroodut.ac.ir, \\ P.mahdavi@gsi.ir
}

Received 8 May 2016; accepted 15 August 2016; published 18 August 2016

Copyright (C) 2016 by authors and Scientific Research Publishing Inc.

This work is licensed under the Creative Commons Attribution International License (CC BY).

http://creativecommons.org/licenses/by/4.0/

c) (i) Open Access

\section{Abstract}

The Gelmandeh Massive is located in the Central part of Iranian Microcontinent. Amphibolitic rocks occupy the main portion of Gelmandeh complex, which consists of hornblendite, garnet amphibolites, and gneiss. Geochemical investigations indicate that the ratio of Eu/Eu* separates samples into two categories: first category with ratio of $\mathrm{Eu} / \mathrm{Eu}^{*}>1$ and the second with ratio of $\mathrm{Eu} / \mathrm{Eu}^{*}<1$, which the former indicates an enriched mantle origin while the latter points to crustal contamination. Generally, amphibolites can be differentiated into two separate series. First series is characterized with calc-alkaline to alkaline composition with enriched mantle origin, and the second one has calc-alkaline to tholeiitic nature and it is of continental type that underwent crustal contamination within subduction zone. The microprobe electron analysis shows that the amphiboles were a member of the calcic group and hastingsite-tschermakite series. Geo-barometric studied and mineral paragenesis show that the metamorphism is of Barovian type with PT condition upto $7 \mathrm{~K}$ bar and $580^{\circ} \mathrm{C}$.

${ }^{*}$ Corresponding author.

How to cite this paper: Gourabjeiri-Pour, A., Heuss-Aßbichler, S., Mobasheri, M. and Mahdavi, P. (2016) Geochemistry, Mineral Chemistry and Thermobarometry of Boneh-Shorou Amphibolites in Gelmandeh Massive (Saghand-Central Iran). Open Journal of Geology, 6, 786-800. http://dx.doi.org/10.4236/ojg.2016.68061 


\section{Keywords}

\section{Amphibolite, Mineral Chemistry, Thermobarometry, Gelmandeh Massive, Boneh-Shorou, Central Iran}

\section{Introduction}

The studied area is located within Yazd Province, and can be seen in some geological quadrangles such as Ardakan 1:250,000 [1], Saghand 1:100,000 [2], Chah-miyoonteh 1:25,000 (Block 70 of Ardakan quadrangle), numbered as 7055II NE. Its geographic coordinates limited within 55, 22, 30 to 55, 30, 00 eastern longitudes, and 32, 45, 00 to 32, 37, 30 northern latitudes, all located in geographic zone 40. Based on geological-structural classification of Iran, this area is considered as part of Central Iran zone and Kalmard-Posht-e-Badam block. Geomorphologically, this area can be divided into two parts, and Posht-e-Badam fault is the departing line trending NE-SW that divides the area into two eastern and western parts. This fault changes direction near the city of Saghand as its trend shifts toward NW-SE. The eastern part mainly consists of low mounds which crop out through a series of desert flats whereas the western part of the fault includes wide short "KALUTs". The western part consists of geologic complexes namely Posht-e-Badam, Chatak, Chapedony and Naybaz featuring ages ranging from Late Paleozoic to Eocene and present (Figure 1).

The eastern part of the fault is older than the western part, and it is indeed a part of Iran's basement. This part consists of geologic complexes such as Zamanabad, Boneh Shorou and Tashk. The oldest rock units of this part include a series of slate, micaschist, quartzite, metagraywacke, volcaniclastics, and mafic lavas, which has been known and introduced as Tashk Formation. This formation contains clastic zircons with age of 627 million years.

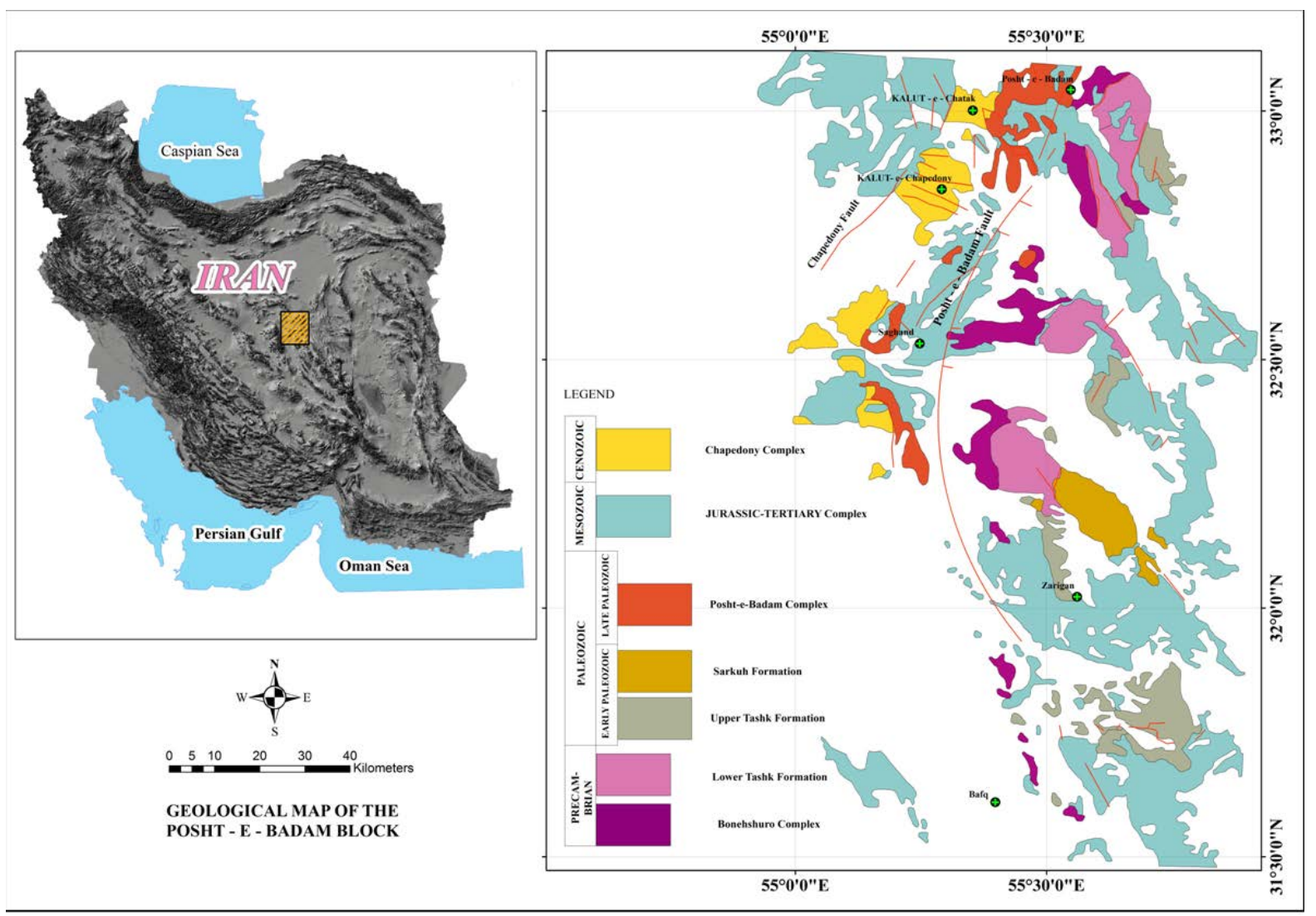

Figure 1. A general view of the studied area and the location of identified geologic complexes on both sides of Posht-e-Badam fault. 
This rock unit is covered with volcano-clastic complex with age of Cambrian [3]. Thereafter, a shallow marine carbonate rock unit with age of Permian-Triassic sits atop Cambrian rock unit with an angular unconformity, and furthermore, an Orbitolina-bearing clastic carbonate rock unit with age of Cretaceous (Albian-Aptian) covers the older rock units, yet again with an angular unconformity. Boneh-shorou Complex consists of a series of micaschist, gneiss, amphibolites, marble and quartzite, in which amphibolites containing large garnet grains are abundant within this complex. Metamorphosis age of these amphibolites was dated as old as $547 \pm 2$ million years [4], which intercalated with micaschist and were cut through by granitic intrusive bodies (now as gneiss) with age of 533 years old [4].

\section{Gelmandeh Massive}

This massive is in form of an oval upheaval trending NW-SE that sits between Allahabad desert and eastern part of Posht-e-Badam fault. It is part of Boneh-shorou complex, and is of great importance to be studies as Iran's basement. Figure 2 shows a three-dimensional (3D) view of Gelmandeh massive, which is an assemblage of IRS and Aster satellite images with scale of 1;25,000. These satellite images have been used as base for compilation of geological map of Gelmandeh mound with scale of 1:25,000. Figure 3 shows the geological map of Gelmandeh massive.

\section{Methodology and Procedure}

Conducting and performing a geological research project considering its experimental nature as well as the research concepts include specific methods that can be divided in three major parts as it follows: 1) Field visits and introductory sampling, 2) Lab studies, 3) Office works to prepare and compile the results and findings from previous.

Two steps during the course of this project, which are described below:

a) Field studies and sampling,

b) Date gathering, preparation and processing of Aster satellite images with resolution of 15 meters in assemblage with IRS satellite images with resolution of 5 meters in order to compile geological map of the studied area,

c) Field studies and sampling from rock units both in form of normal and positional approaches, and structural measurements,

d) Lab studies including thin sections, total rock analysis, and electron-microprobe studies,

e) Analysis and compilation of data.

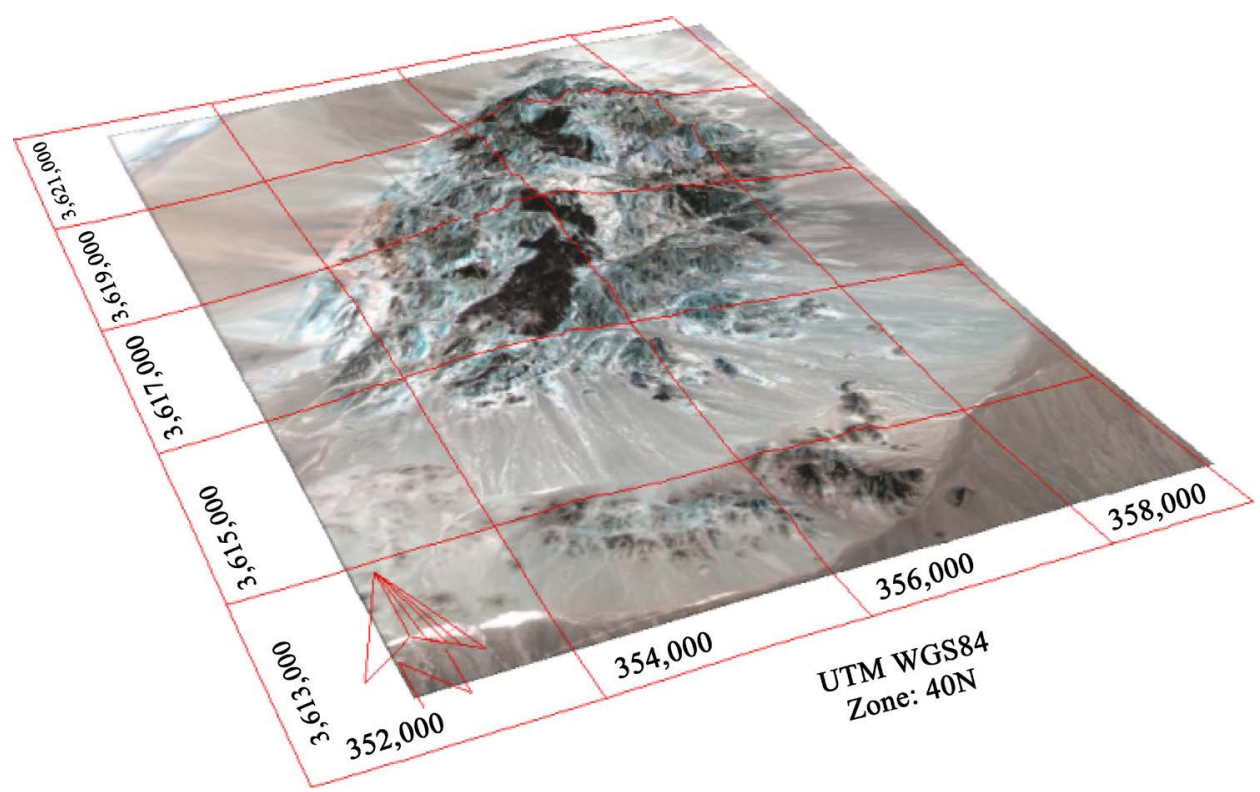

Figure 2. Three-dimensional (3D) view of Gelmandeh massive, which is an assemblage of IRS and Aster. 


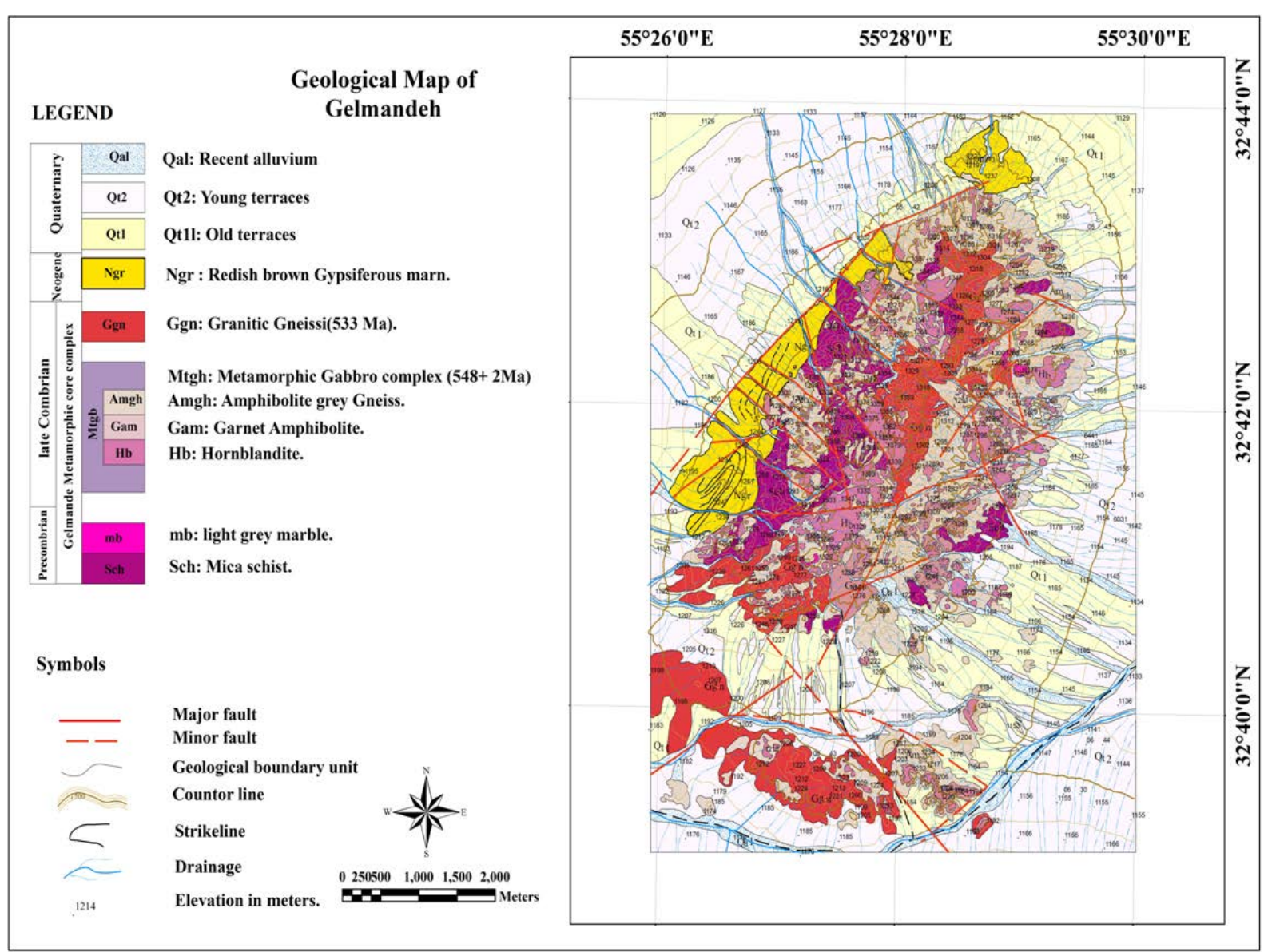

Figure 3. Geological map of Gelmandeh massive.

\section{Lab Studies}

Based on the results from thin section studies, several samples were selected out of total samples taken from the studied area to be sent to lab for the purpose of total rock analysis both for geochemical analysis and electron microprobe mineralogy point analysis. Total rock analysis for 43 elements was performed using ICP method by ALS lab in Canada. The analysis method for 10 major oxide elements was chosen to be ME-ICP06, and MEMS81 for rare elements.

After sample preparation, mineralogical analysis using electron micro probe analyses method performed by SX100 machine in Maximillian University in Hamburg, Germany.

\section{Petrography and Mineral Distribution}

Amphibolitic rock unit occupies the main portion of Gelmandeh massive, which consists of three parts of hornblendite (large amphibolites), garnet-amphibolites, and gray mafic gneiss. The distinctive features of this unit are its dark color (dark green to black) and large garnet grains that in some cases their size reaches to $2.5 \mathrm{~cm}$.

\subsection{Hornblendite}

Hornblendites are identified with high content of large-grained and multi-colored hornblendes (green-blue) in such way that hornblendes often form $90 \%$ of the rock volume, and their size reaches to 8 mm in some areas. This rock unit contains low amount of plagioclase and quartz along with secondary minerals such as sphene and apatite. Amphiboles are usually fully-shaped to amorphous with no distinct foliation, however amphibole needles show orientation. Amphiboles in hornblendite thin sections are less conspicuous and fewer multi-coloreds as compared to those in gneiss and amphibolites (Figure 4(a), Figure 4(b)). 


\subsection{Garnet-Amphibolites}

Garnet-amphibolites are characterized with granular to nematoblastic texture and large pink garnet grains, but without a distinguishable banded structure. Among other characteristics of this unit, it can be referred to existence of intact green-blue amphiboles with good prominence (Figure 5(a), Figure 5(b)), and plagioclases with albitic macle and somehow sericitized. Biotite, epidote and sphene are among the secondary minerals of this rock unit. Garnets are mostly of almandine-grossular composition, and lack zoning (Figure 6(a), Figure 6(b)). They are altered along the fractures and transformed to chlorite and quartz. Amphiboles are generally seen as semi-shaped to amorphous, but mostly in form of short to long columns or wide rods to somewhat columnar. They are rarely seen as automorphous, but seen in form of hexagonal in cross sections. Bluish green color is one of their characteristics. Based on Figures 7(a)-(c) they fall in calcic amphiboles group, green hornblende family and hastingsite-tschermakite series.

\subsection{Amphibolitic Gneiss}

Amphibolitic gneisses or gray mafic gneisses are characterized with large porphyroclastic plagioclases and biotites, which show signs of mylonitization and foliation due to mylonitization. This rock unit often contains pink garnets that are seen as amorphous and rounded with many fractures in the thin sections. Plagioclases are usually heavily altered in the central parts, which show accumulations rich in epidote and calcium. Among other characteristics of this rock unit it can be referred to existence of amphiboles with good prominence and strong blue-green multi-coloration that are mainly seen along the edges of these garnets (Figure 8(a), Figure 8(b)).

Transformation of mafic gneisses to amphibolites sub-unit is characterized by increase of hornblende content and garnet size, and also evidence of mylonitization.

\section{Geochemistry}

Total rock geochemical study of amphibolites in Gelmandeh massive is based on analysis results from 11 samples that were studied and analyzed for 43 elements in ALS lab in Canada. Table 1 shows the results from analysis of main elements oxides as well as the results from related calculations in details.

This complex in Gelmandeh massive is remarkably widespread, and based on the field evidences, its origin can be associated with a dark-colored gabbro-basaltic body. Signs and evidences of penetration of this intrusive
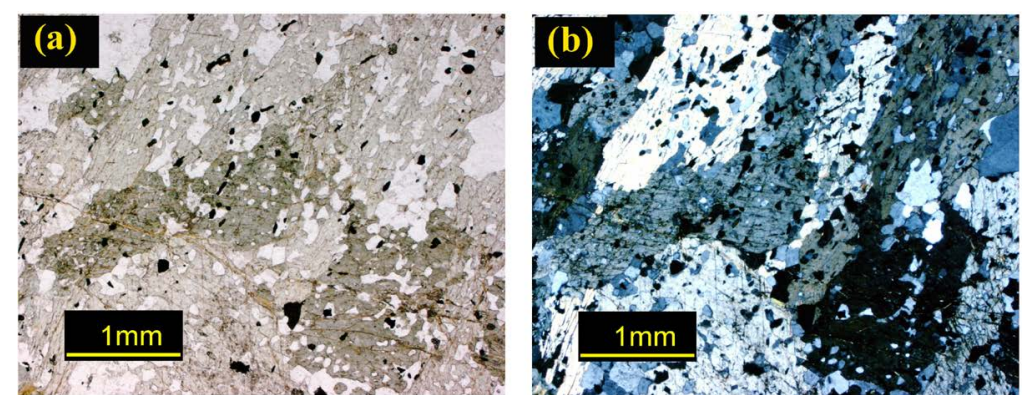

Figure 4. A microscopic view of amphiboles in amphibolitic unit (magnified of 2.5 times) (a) PPL; (b) XPL.

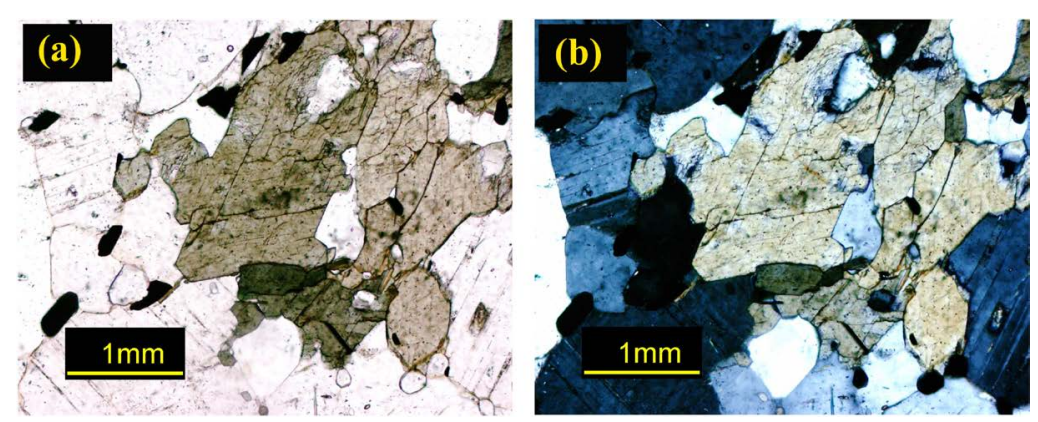

Figure 5. Amphibole in garnet-amphibolite unit shown in thin section (magnified by 10 times) (a) PPL; (b) XPL. 

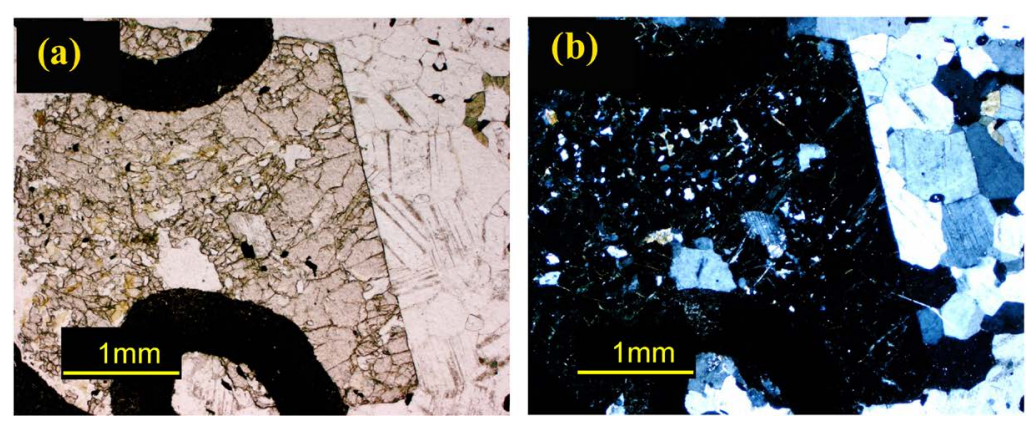

Figure 6. A microscopic view of semi-shaped garnet in garnet-amphibolitic unit (magnified by 2.5 times) (a) PPL; (b) XPL.
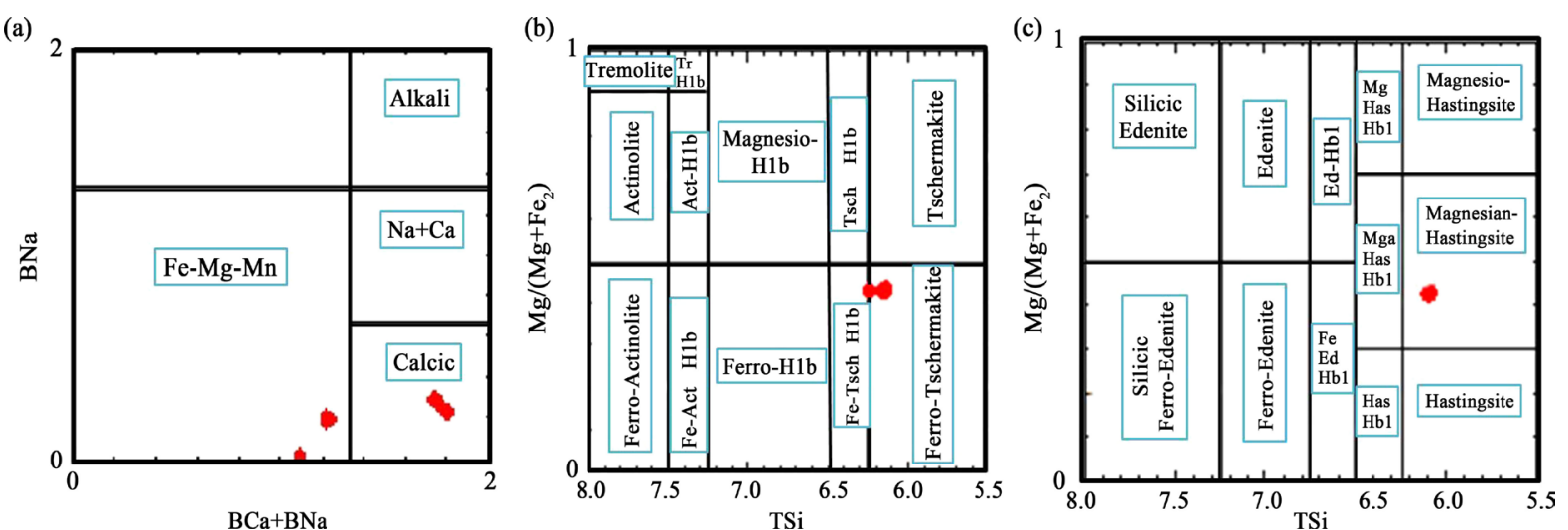

Figure 7. (a) Chemical composition of the amphiboles analysed plotted on BNa/BCa + BNa diagram, (b) Determination of amphibole series based on Ana $+\mathrm{AK}<0.5$; $\mathrm{Ti}<0.5$, (c) Determination of amphibole series based on $\mathrm{Na}+\mathrm{AK}>0.5$; $\mathrm{Ti}<$ 0.5 ; Fe > Alvi.

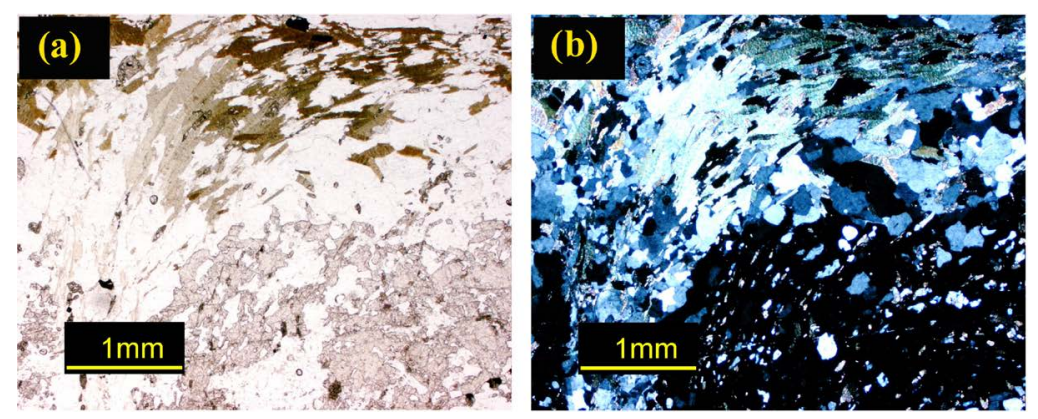

Figure 8. Formation of eye-shaped structure around garnet crystal in mafic gneiss unit (magnified by 2.5 times) (a) PPL; (b) XPL.

body are frequently seen in older parts.

According to Table 1 the content of $\mathrm{SiO}_{2}$ varies from 45 to 57 with an average of $51.3 \%$, and $\mathrm{Al}_{2} \mathrm{O}_{3}$ content ranges from 10 - 1 with average of 14.4. The variation range of other major elements oxides such as $\mathrm{Fe}_{2} \mathrm{O}_{3}$ varies between 6.77 and 15.5, $\mathrm{CaO}$ between 5.02 and $12.3, \mathrm{Na}_{2} \mathrm{O}$ between 1.26 and $7.23, \mathrm{~K}_{2} \mathrm{O}$ between 0.26 and 2.81, $\mathrm{TiO}_{2}$ between 0.63 and 3.65, $\mathrm{MnO}$ between 0.09 and 0.36 , and $\mathrm{P}_{2} \mathrm{O}_{5}$ between 0.14 and 0.88 . Accordingly, the variation of degree of saturation of Aluminum (A/CNK) ranges between 0.87 and 1.06, the ratio of Mg\# varies from 0.44 to 0.52 , and A' index changes between 1.76 and 1.86 . Such variations match the average/median of continental basalts.

R1-R2 [5] diagram have been used in order to name and identify the source rock of these amphibolites and to support petrographic studies (Figure 9(a)). In this diagram the nature of samples varies from gabbro to gabbro-diorite, monzo-gabbro and diorite.

In addition, other diagrams such as $\mathrm{Zr} / \mathrm{Ti}-\mathrm{Nb} / \mathrm{Y}$ [6] and Co-Th [7] differentiate these rocks as two complexes 
Table 1. The results of major elements total rock analysis, in Gelmandeh-Saghand area.

\begin{tabular}{|c|c|c|c|c|c|c|c|c|c|c|c|}
\hline Sample & $\begin{array}{c}\text { GL1 } \\
\text { S3 }\end{array}$ & $\begin{array}{l}\text { GL6 } \\
\text { S22 }\end{array}$ & $\begin{array}{l}\text { GL9 } \\
\text { S38 }\end{array}$ & $\begin{array}{c}\text { GL10 } \\
\text { S42 }\end{array}$ & $\begin{array}{c}\text { GL15 } \\
\text { S60 }\end{array}$ & $\begin{array}{c}\text { GL17 } \\
\text { S64 }\end{array}$ & $\begin{array}{c}\text { GL18 } \\
\text { S71 }\end{array}$ & $\begin{array}{l}\text { GL21 } \\
\text { S76 }\end{array}$ & $\begin{array}{c}\text { GL23 } \\
\text { S81 }\end{array}$ & $\begin{array}{c}\text { GL25 } \\
\text { S83 }\end{array}$ & $\begin{array}{c}\text { GL11 } \\
\text { S53 }\end{array}$ \\
\hline \multicolumn{12}{|c|}{ WT\% } \\
\hline $\mathrm{SiO}_{2}$ & 55.5 & 57.9 & 46.7 & 54.5 & 53.9 & 50.6 & 43.8 & 55.5 & 48.8 & 55.5 & 49 \\
\hline $\mathrm{Al}_{2} \mathrm{O}_{3}$ & 18.9 & 14.6 & 14.45 & 13.8 & 15.2 & 16.7 & 11.45 & 18.9 & 14.2 & 15.3 & 10.1 \\
\hline $\mathrm{Fe}_{2} \mathrm{O}_{3}$ & 6.77 & 8.72 & 12.7 & 11.8 & 10.7 & 10.1 & 15.5 & 6.77 & 14.3 & 8.95 & 12.5 \\
\hline $\mathrm{CaO}$ & 5.19 & 6.51 & 8.25 & 5.02 & 8.95 & 8.72 & 11.05 & 5.19 & 8.39 & 6.67 & 12.3 \\
\hline $\mathrm{MgO}$ & 1.46 & 5.26 & 6.82 & 2.68 & 4.65 & 6.02 & 9.34 & 1.46 & 4.56 & 3.77 & 8.3 \\
\hline $\mathrm{Na}_{2} \mathrm{O}$ & 7.32 & 2.94 & 3.16 & 3.01 & 2.82 & 3.09 & 1.74 & 7.32 & 2.52 & 3.56 & 1.26 \\
\hline $\mathrm{K}_{2} \mathrm{O}$ & 0.26 & 1.86 & 0.43 & 2.81 & 1.05 & 1.66 & 0.52 & 0.26 & 0.85 & 1.26 & 0.36 \\
\hline $\mathrm{Cr}_{2} \mathrm{O}_{3}$ & 0 & 0.04 & 0.02 & 0 & 0.01 & 0.05 & 0.07 & 0 & 0.02 & 0.01 & 0.11 \\
\hline $\mathrm{TiO}_{2}$ & 1.22 & 0.63 & 2.79 & 2.35 & 1.32 & 0.97 & 3.03 & 1.22 & 2.94 & 1.38 & 2.31 \\
\hline $\mathrm{MnO}$ & 0.09 & 0.14 & 0.13 & 0.13 & 0.16 & 0.21 & 0.21 & 0.09 & 0.36 & 0.15 & 0.23 \\
\hline $\mathrm{P}_{2} \mathrm{O}_{5}$ & 0.88 & 0.14 & 0.42 & 0.74 & 0.32 & 0.23 & 0.38 & 0.88 & 0.23 & 0.28 & 0.34 \\
\hline $\mathrm{SrO}$ & 0.08 & 0.03 & 0.06 & 0.05 & 0.03 & 0.03 & 0.02 & 0.08 & 0.03 & 0.03 & 0.08 \\
\hline $\mathrm{BaO}$ & 0.03 & 0.04 & 0.02 & 0.12 & 0.02 & 0.04 & 0.01 & 0.03 & 0.04 & 0.06 & 0.01 \\
\hline LOI & 0.49 & 1.07 & 2.13 & 1.18 & 1.37 & 1.17 & 0.98 & 0.49 & 0.88 & 1.17 & 1.18 \\
\hline Total & 98.2 & 99.9 & 98.1 & 98.2 & 100.5 & 99.6 & 98.1 & 98.2 & 98.1 & 98.1 & 98.1 \\
\hline \multicolumn{12}{|c|}{ MOL\% NCKFMAS } \\
\hline $\mathrm{S}$ & 2662.7 & 3210.7 & 2603.1 & 3084.5 & 3039.5 & 2776.2 & 2633.2 & 2815.8 & 2942.0 & 3120.7 & 2969.7 \\
\hline A & 2368.4 & 1828.5 & 2120.1 & 2264 & 1947.8 & 2084.7 & 1964.1 & 2575.7 & 2272.1 & 2029.4 & 1566.4 \\
\hline $\mathrm{F}$ & 2.91 & 3.39 & 3.46 & 3.59 & 3.72 & 3.78 & 4.61 & 2.18 & 4.29 & 2.98 & 3.73 \\
\hline M & 288.56 & 325.69 & 359.73 & 108.65 & 264.95 & 371.59 & 529.24 & 62.25 & 227.56 & 211.42 & 471.54 \\
\hline $\mathrm{C}$ & 1008.8 & 892.46 & 904.98 & 877.93 & 959.86 & 1043.6 & 947.7 & 1206.4 & 937.6 & 945.06 & 937.76 \\
\hline $\mathrm{N}$ & 3.96 & 3.05 & 3.31 & 3.32 & 2.93 & 3.25 & 1.86 & 8.1 & 2.79 & 3.81 & 1.31 \\
\hline K & 0.75 & 1.27 & 0.3 & 2.04 & 0.72 & 1.15 & 0.37 & 0.19 & 0.62 & 0.89 & 0.25 \\
\hline $\mathrm{A} / \mathrm{CNK}$ & 0.68 & 0.78 & 0.7 & 0.8 & 0.69 & 0.73 & 0.49 & 0.87 & 0.7 & 0.79 & 0.41 \\
\hline Mg\# & 0.63 & 0.68 & 0.66 & 0.45 & 0.61 & 0.68 & 0.68 & 0.44 & 0.53 & 0.6 & 0.71 \\
\hline
\end{tabular}

(a)

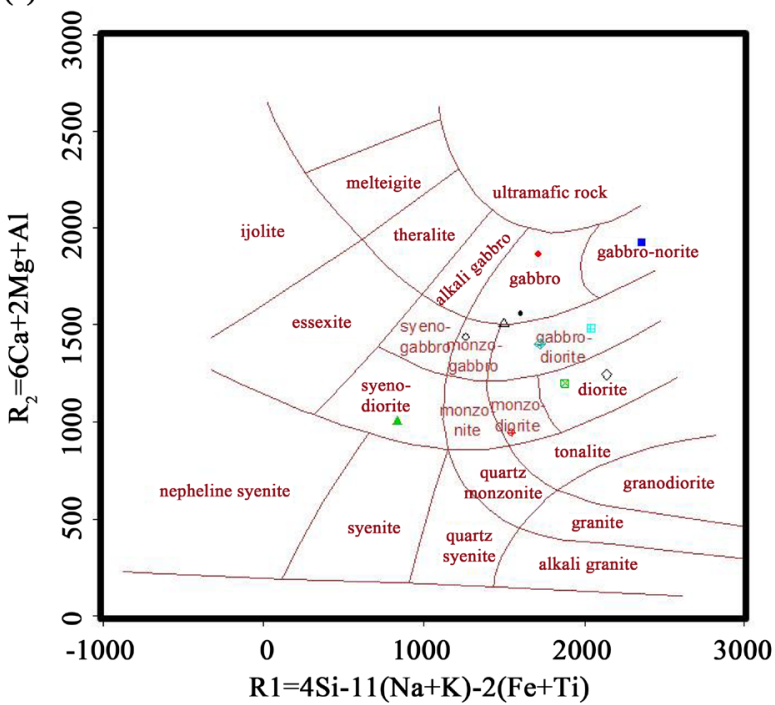

(b)

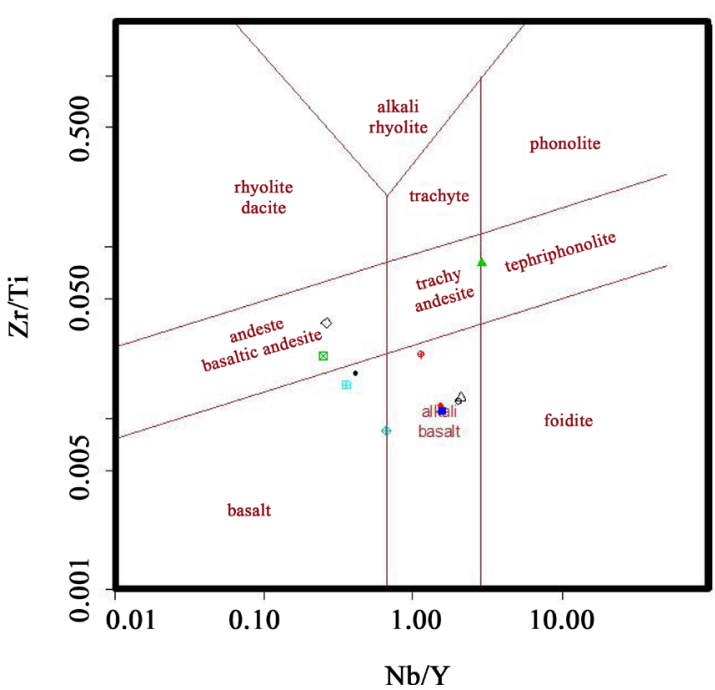

Figure 9. (a) Classification of intrusive rocks with use of R1 and R2 parameters [5], (b) Geochemical classification and names of extrusive rocks with use of $\mathrm{Nb} / \mathrm{Y}-\mathrm{Zr} / \mathrm{Ti}$ [6]. 
of basalt and alkali-basalt with nature of calc-alkaline to potassic calc-alkaline (Figure 9(b), Figure 10). Magmatic genes for samples observed in diagram Irvine and Baragar [8]. The variation of major elements oxides and rare elements against $\mathrm{MgO}$ are shown in (Figure 11, Figure 12). While the distribution pattern of samples indicates a discontinuity, it also follows the differentiation trend. At such state $\mathrm{Al}_{2} \mathrm{O}_{3}, \mathrm{SiO}_{2}, \mathrm{~K}_{2} \mathrm{O}$ and $\mathrm{Na}_{2} \mathrm{O}$ show descending trend whereas the trend of the rest of elements is ascending. On the other hand, the descending trend

(a)

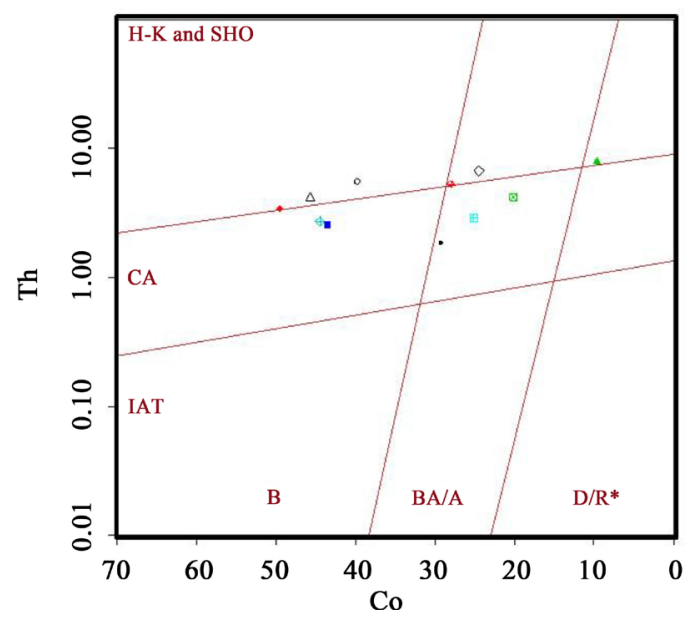

(b)

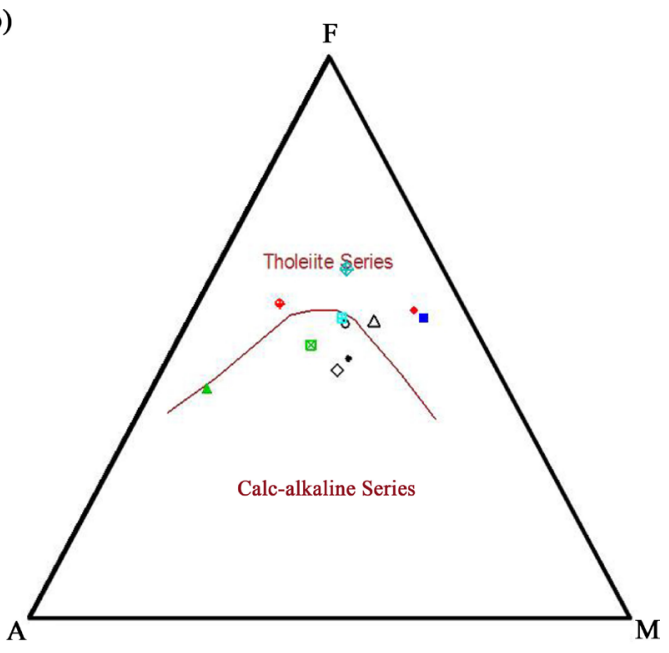

Figure 10. (a) Classification of basic rocks with use of variation of Co in relation to Th [7]. Rock samples in this diagram are divided into two groups of basalt and alkali-basalt, which fall in calc-alkaline to high potassium calc-alkaline magmatic series territory, (b) Variation of Iron percentage in different magmas during the course of differentiation for separation of tholeiitic and calc-alkaline series [8].
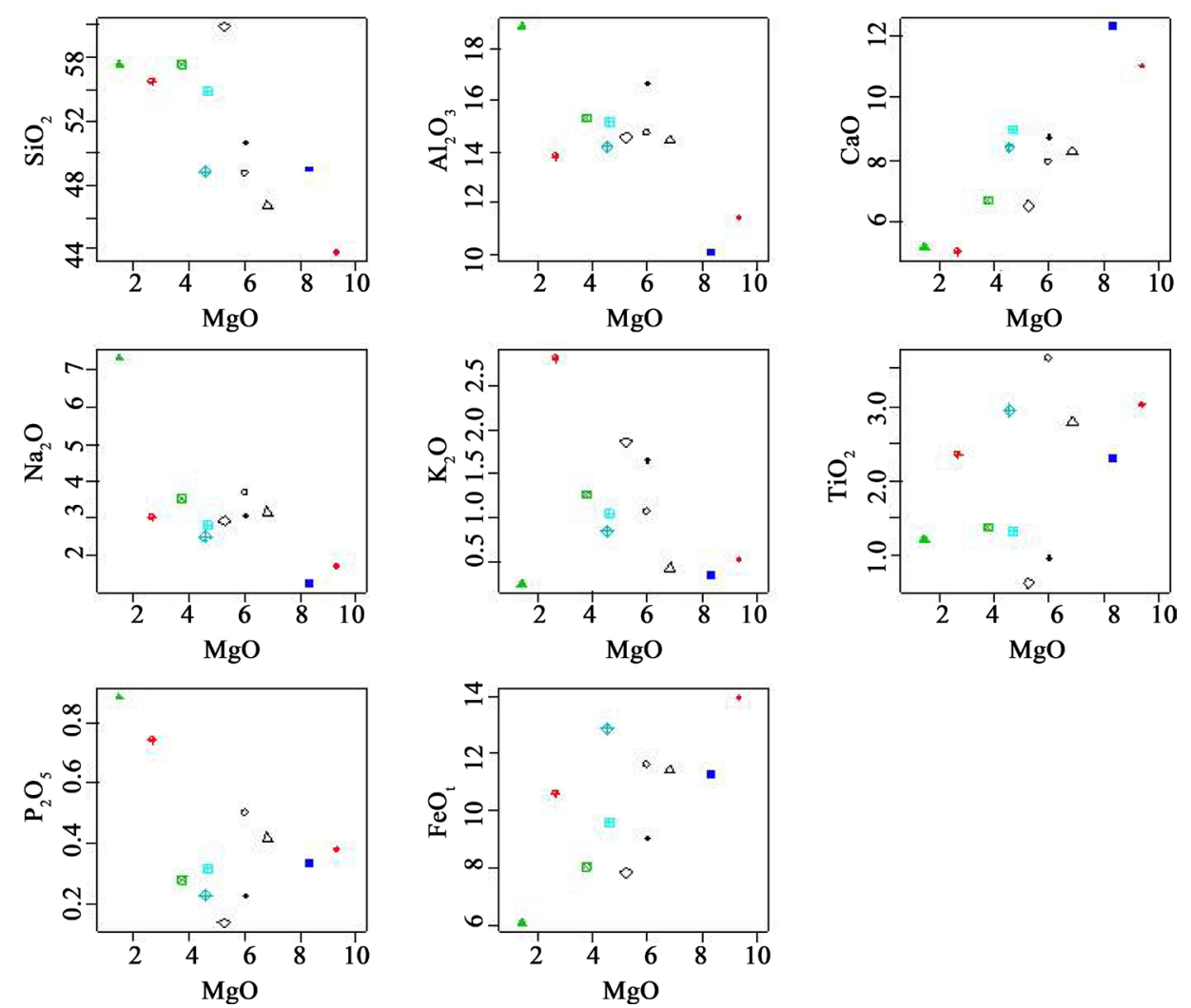

Figure 11. Variation of major element oxide in relation to $\mathrm{MgO}$ [11]. 

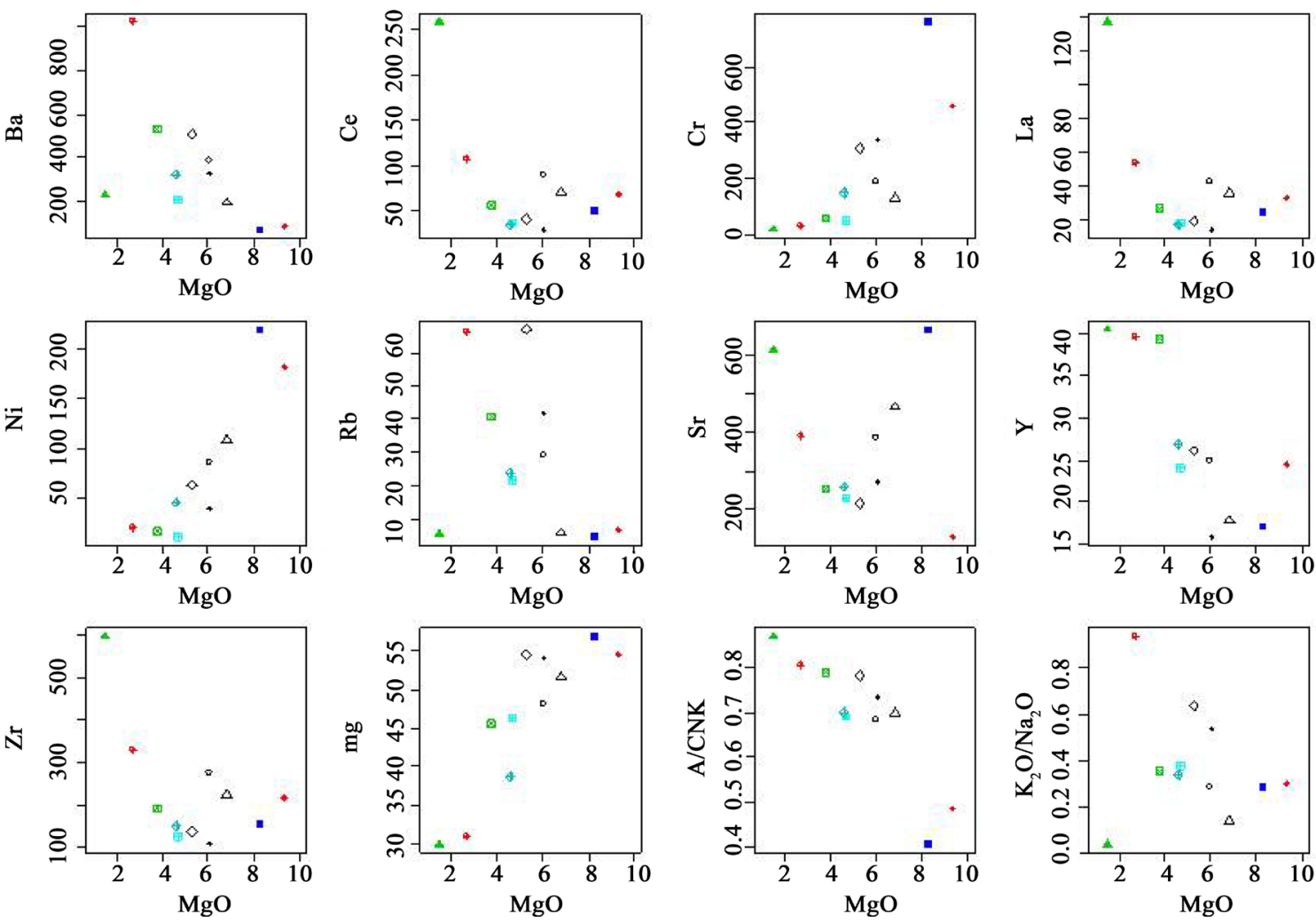

Figure 12. Variation of rare elements oxide in relation to $\mathrm{MgO}$ [11].

of $\mathrm{Ni}$ and $\mathrm{Cr}$ in rare elements is remarkable, and $\mathrm{Y}, \mathrm{Ce}, \mathrm{Ba}, \mathrm{Zr}, \mathrm{Rb}$ and alkaniteh show descending trend too. Crystalline liquid distribution coefficient data shows that during partial melting $\mathrm{Ni}$, $\mathrm{Ca}$ and $\mathrm{Cr}$ separate away from olivine crystalline differentiation process. Therefore, distribution and abundance of such elements is a useful indication for petrogenetic processes. So far, the study of major and rate elements in Harker diagram not only confirms and verifies the magmatic origin for amphibolites but also indicates that formation of amphiboles associates with two different origins or happened during two different time spans.

Study of rare elements in spider diagrams (Figures 13-15) and normalization of data based on chondrite content yield interesting evidences in this section. The ratio of $\mathrm{Eu} / \mathrm{Eu}^{*}$ separates samples in two categories; one category with ratio of $\mathrm{Eu} / \mathrm{Eu}^{*}>1$ and the other with ratio of $\mathrm{Eu} / \mathrm{Eu}^{*}<1$, which the former one indicates to an enriched mantle origin while the latter one points to crustal contamination.

The ratio of $(\mathrm{La} / \mathrm{Sm})>1$ also confirms the enriched mantle origin for formation of amphibolites. Figure 13 shows all samples in a chondrite-based normalized spider diagram [9]. This diagram clearly presents different origins for these types of rocks. Based on this fact the samples were divided apart and spider diagram was drawn for each part again. Samples GL1S3, GL9S38, GL11S53, GL18S71 and GL21S76 were allocated to one part and the rest of the samples to the other part. Figure 14 shows enrichment for $\mathrm{Th}, \mathrm{Nb}$, Ta and Ti elements and impoverishment for $\mathrm{Rb}, \mathrm{K}$ and $\mathrm{Sr}$ elements, which implies to enriched mantle origin of alkaline-basalt type within oceanic or crustal plates.

Figure 15 shows variation of samples GL25S86, GL23S81, GL47S64, GL45S60, GL10S42 and GL6S22 in spider diagram. The samples show impoverishment for $\mathrm{P}, \mathrm{Ti}, \mathrm{Ta}, \mathrm{Nb}$ and Th elements whereas enrichment for $\mathrm{Rb}, \mathrm{K}$ and $\mathrm{Nd}$ elements. Impoverishment of $\mathrm{Nb}$ and $\mathrm{Ti}$ is specific to magmas that undergo crustal contamination process within a tectonic setting associated with subduction.

According to Wood [10] diagram (Figure 16), it assigns the first series of samples to continental alkaline-basalt territory and the second series of samples to continental tholeiitic-basalt territory.

Taking all data and findings into account, two geneses are confirmed for the origin of amphibolites although petrographic studies do not show significant difference between these two geneses. Accordingly, amphibolites can be differentiated into two separate series. First series is characterized with calc-alkaline to alkaline composi- 
tion with enriched mantle origin of continental type, and the second one has calc-alkaline to tholeiitic composition and it is of continental type that underwent crustal contamination within subduction zone, which is probably younger than the first series.

\section{Thermo-Barometry}

The best method to determine the temperature and pressure condition affecting the studied area at the time is to

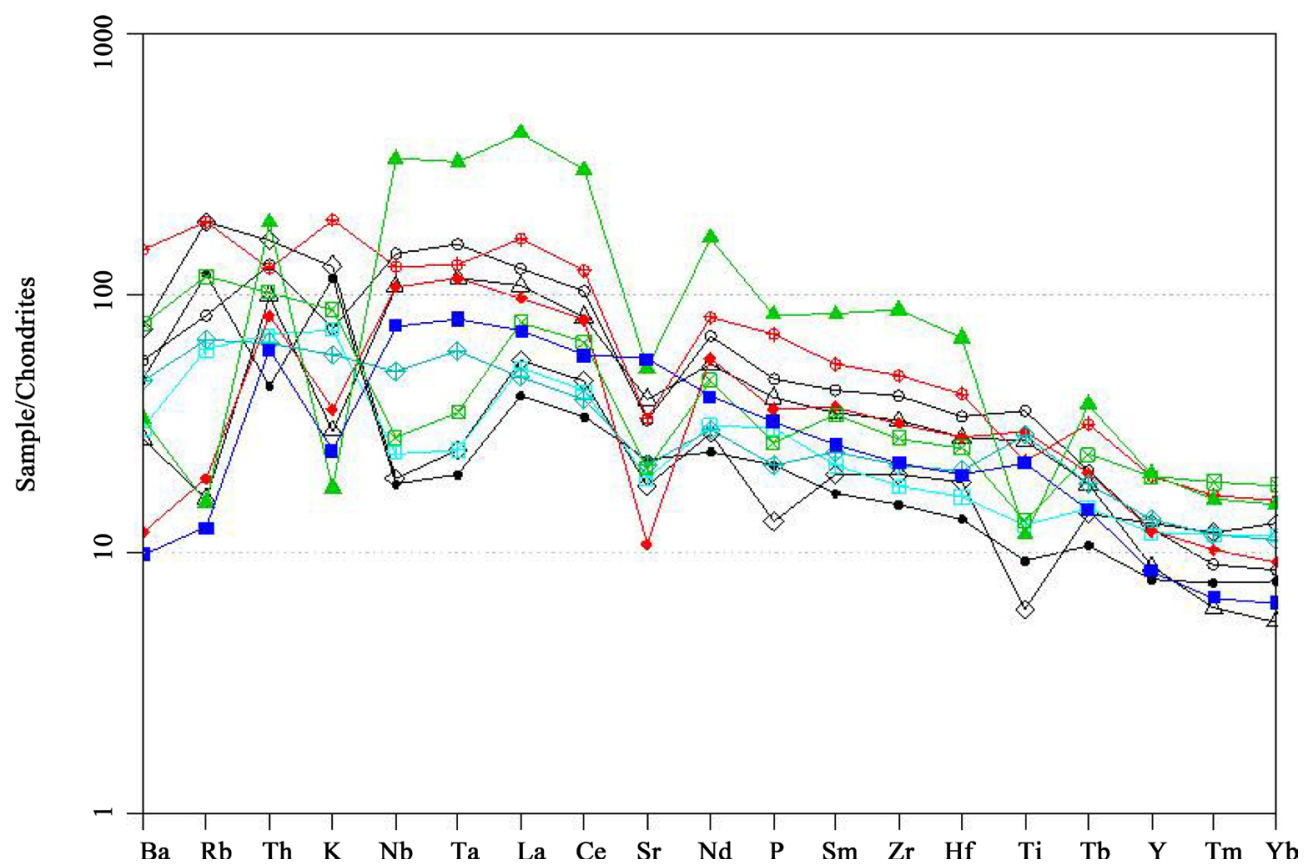

Figure 13. Chondrite-based normalized spider diagram [9].

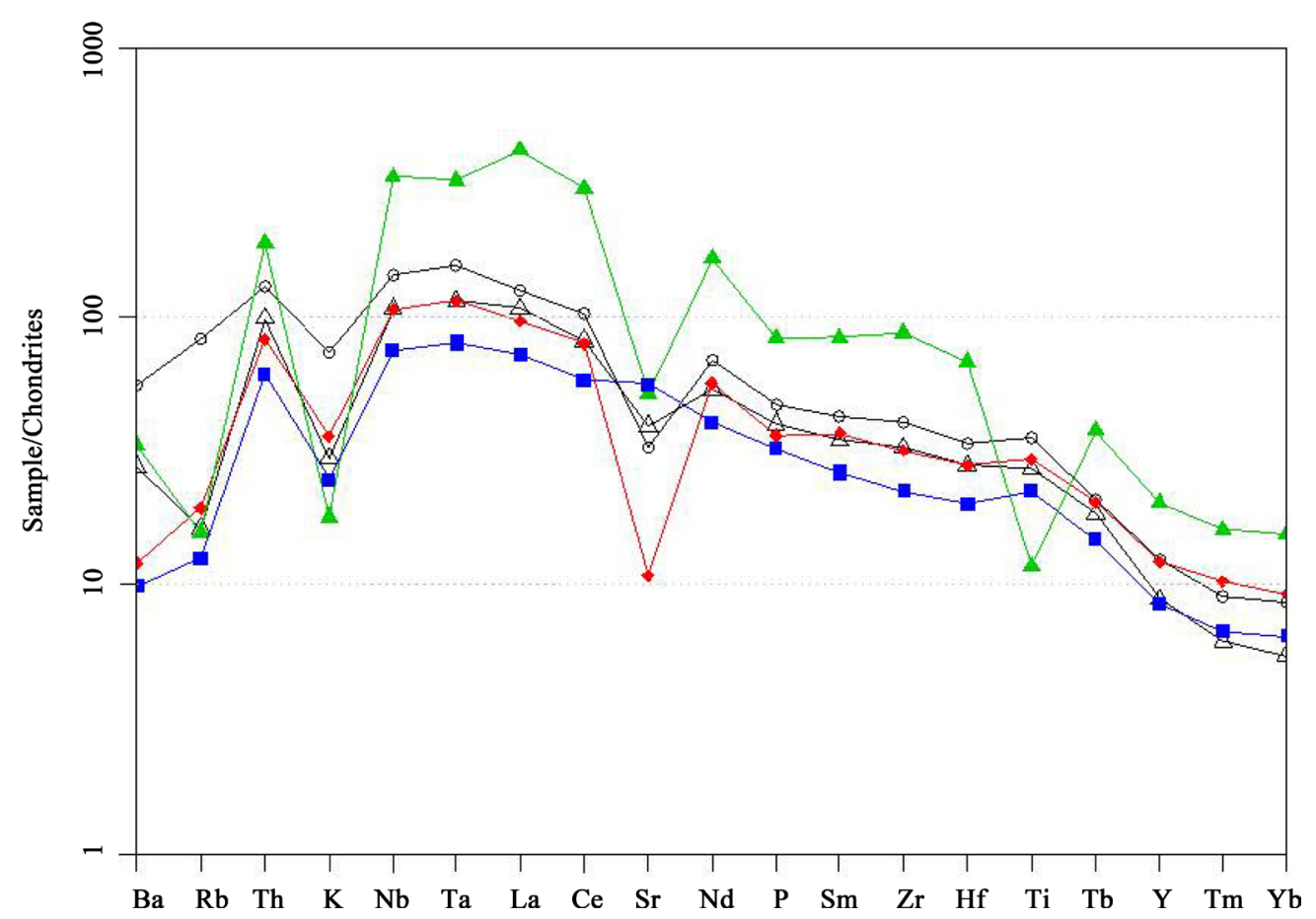

Figure 14. Spider diagram for samples GL1S3, GL9S38, GL11S53, GL18S71 and GL21S76. 


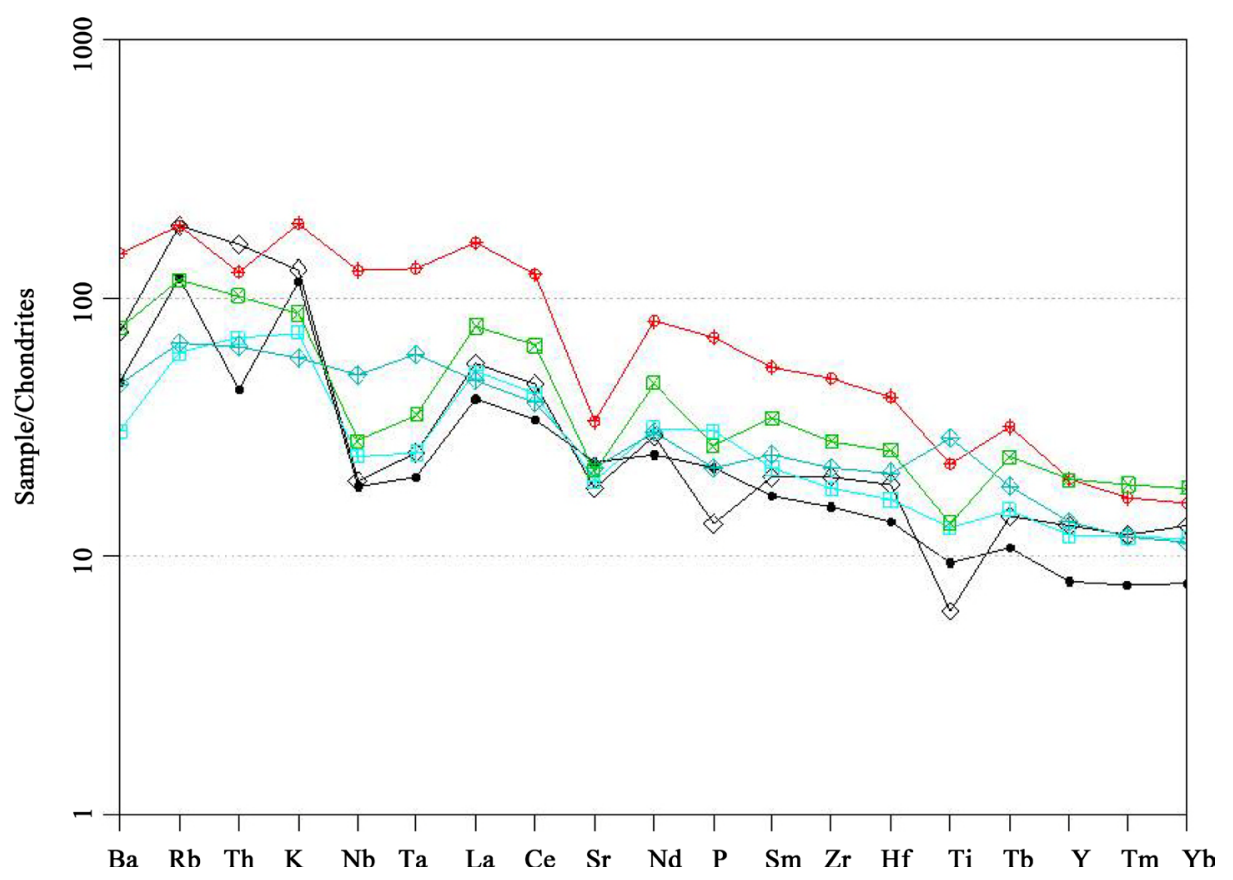

Figure 15. Spider diagram for samples GL25S86, GL23S81, GL47S64, GL45S60, GL10S42 and GL6S22.

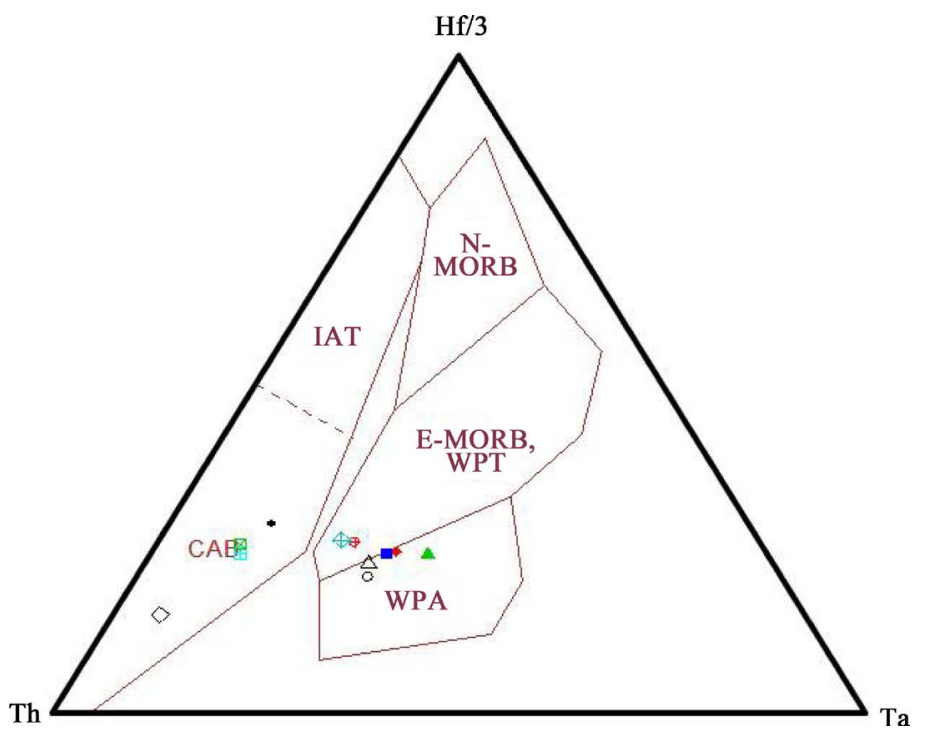

Figure 16. Diagram distinguishing basalts based on Th-Hf-Ta [10]. Samples in the first series fall in a territory between continental alkali-basalt and tholeiits, while the samples in the second series fall in magmatic arc basalt territory.

precisely study the association of minerals with one another as well as the reactions took place among them [12]. The mineralogical association and minerals assemblage have been described in detail in petrography section. Here it is attempted to reconstruct the reactions between minerals and determine the metamorphism conditions based on mineralogical association. At the final stage, the results gained from determination of metamorphic facies based on mineralogical association along with the results from electron microprobe analyses were studied and analyzed using THERMOCALC (Version 2.3) software and temperature and pressure condition for formation of each mineral was determined.

Garnet-amphibolite consists of hornblendes belonged to HANSTINGZIT-CHERMAKIT series (Figure 17(a)), and oligoclase-andesine plagioclase minerals are primary components of this rock unit, wherein amorphous garnet without zoning along (Figure 17(b), Figure 18) with small amount of biotite and quartz are found. 
Greenschist facies minerals in metabasites include chlorite + albite + epidote + actinolite + quartz [12]. During the course of crossing through this facies the following reactions take place (Figure 19).

1) Transformation of plagioclase composition from albite to oligoclase:

$$
\text { Epidote }+ \text { Chlorite }+ \text { quartz }=\text { edenite }+ \text { quartz. }
$$

2) Transformation of amphibole composition from actinolite to hornblende. In this situation and due to structural change, amphiboles acquire more dense composition and leads to formation of hornblendes belonged to CHERMAKIT to PARAGARNET series.

$$
\begin{aligned}
& \text { Tremolite }+ \text { albite }=\text { edenite }+ \text { quartz } \\
& \text { Tremolite }+ \text { chlorite }+ \text { zoisite }+ \text { quartz }=\text { tschermakite }+\mathrm{H}_{2} \mathrm{O} .
\end{aligned}
$$

3) Enrichment of Iron content in chlorite and reduction of epidote.

Mineralogical characteristics of amphibolites indicate to transition through green schist facies and falling in amphibolite facies. Presence of garnet with composition of almandine within the amphibolites points to high percentage of iron content in protoliths, and their growth implies to high-temperature metamorphic condition. Lack of manganese in garnets of the area confirms their magmatic origin.

Table 2 includes the microprobe analyses of garnet, plagioclase and amphibole in sample GL21S76. The
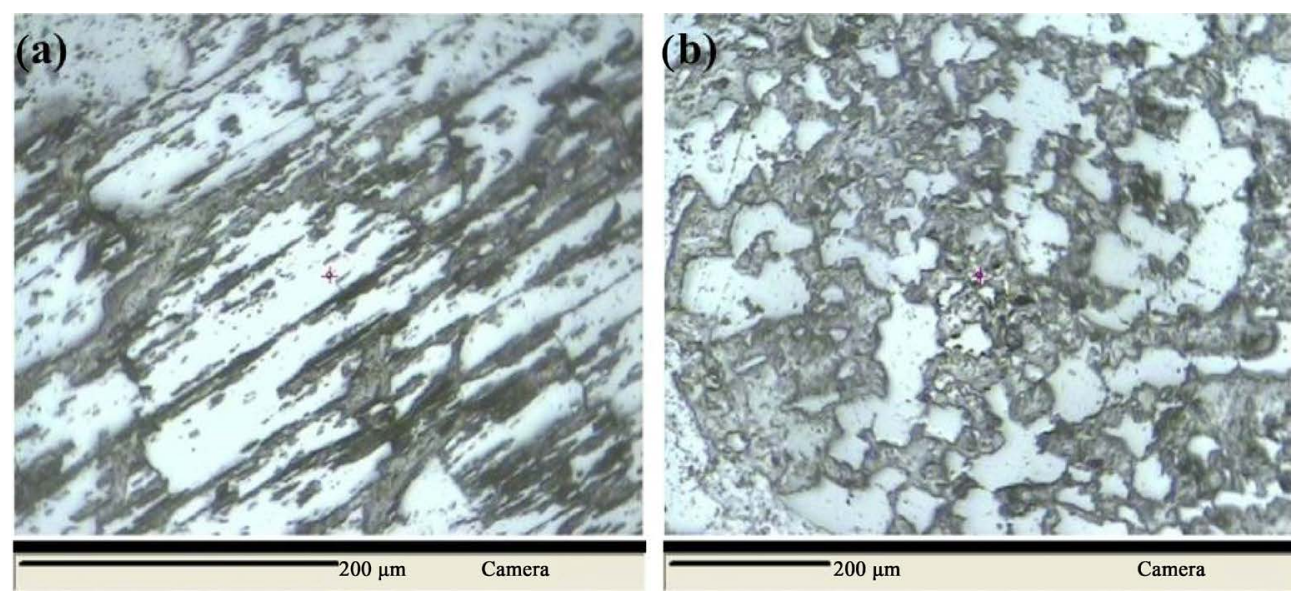

Figure 17. (a) X-Ray image of hornblende mineral, (b) X-Ray image of garnet mineral.

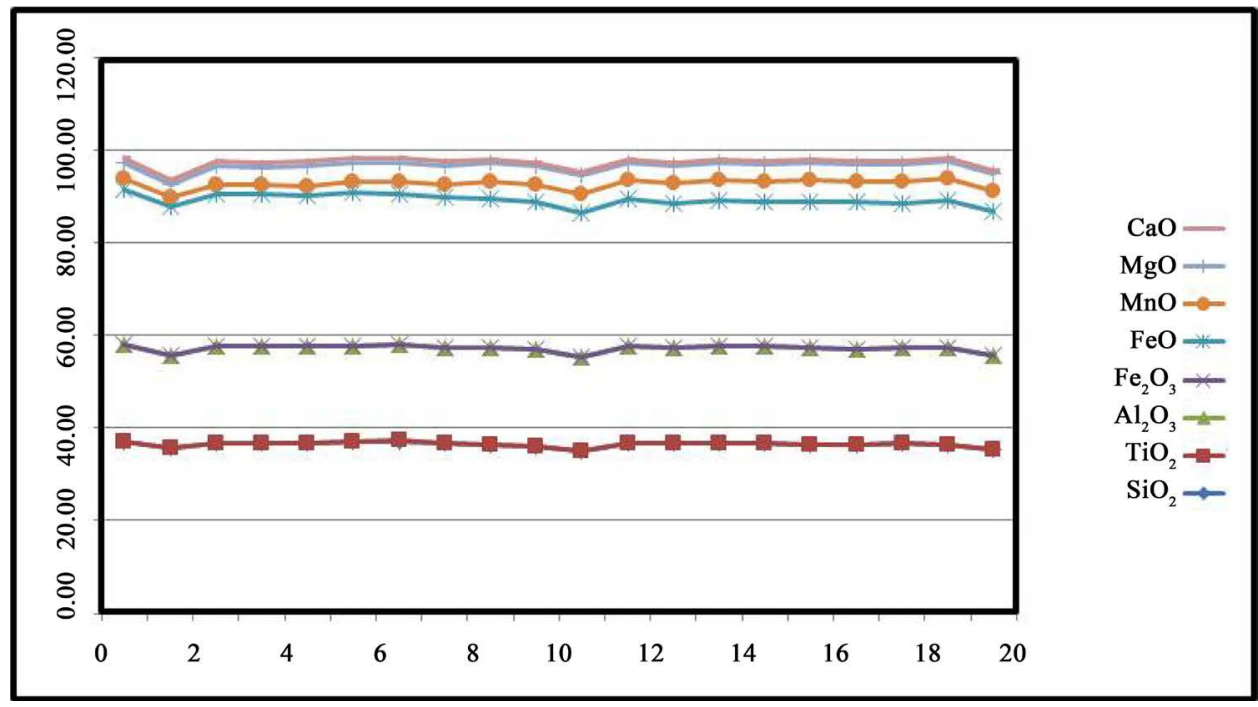

Figure 18. Variation of 20-point composition across garnet mineral, composition homogeneous composition of garnets, and lack of zoning are shown in this diagram. 


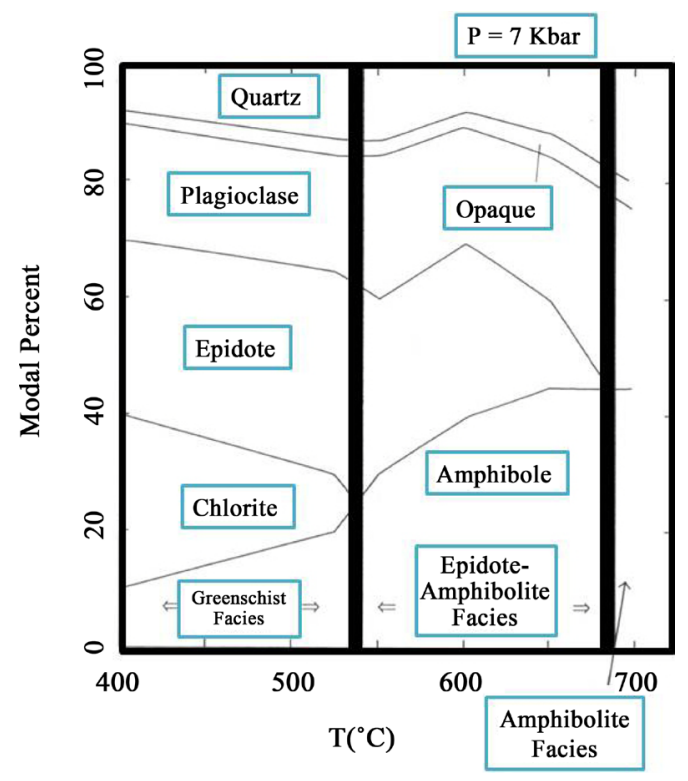

Figure 19. Minerals percentage variation model based on transition of green schist facies through epidote-amphibolite [13].

Table 2. Results from electron microprobe analysis of minerals in sample GL21S76.

\begin{tabular}{|c|c|c|c|c|c|c|c|c|c|c|c|}
\hline Mineral & Lable & $\mathrm{SiO}_{2}$ & $\mathrm{TiO}_{2}$ & $\mathrm{Al}_{2} \mathrm{O}_{3}$ & $\mathrm{Fe}_{2} \mathrm{O}_{3}$ & $\mathrm{FeO}$ & $\mathrm{MnO}$ & $\mathrm{MgO}$ & $\mathrm{CaO}$ & $\mathrm{Na}_{2} \mathrm{O}$ & $\mathrm{K}_{2} \mathrm{O}$ \\
\hline fsp & 1_1 & 65.57 & 0.00 & 22.17 & 0.45 & 0.00 & 0.04 & 0.02 & 3.28 & 6.65 & 0.03 \\
\hline amph & 2_1 & 40.72 & 0.27 & 14.46 & 0.00 & 23.76 & 0.22 & 6.90 & 9.55 & 2.44 & 0.49 \\
\hline amph & 2_2 & 41.28 & 0.26 & 14.72 & 0.00 & 22.49 & 0.19 & 6.72 & 9.06 & 2.11 & 0.31 \\
\hline amph & 2_3 & 40.95 & 0.25 & 14.85 & 0.00 & 23.32 & 0.19 & 6.85 & 9.22 & 2.28 & 0.33 \\
\hline amph & 2_4 & 41.28 & 0.26 & 14.76 & 0.00 & 23.52 & 0.13 & 6.82 & 9.31 & 2.21 & 0.30 \\
\hline amph & 2_5 & 40.49 & 0.20 & 14.41 & 0.00 & 23.62 & 0.17 & 6.88 & 9.82 & 2.38 & 0.44 \\
\hline fsp & 3_1 & 65.73 & 0.02 & 21.87 & 0.24 & 0.00 & 0.02 & 0.00 & 3.13 & 8.92 & 0.05 \\
\hline fsp & 3_2 & 66.55 & 0.01 & 21.36 & 0.18 & 0.00 & 0.01 & 0.03 & 2.61 & 9.31 & 0.03 \\
\hline fsp & 3_3 & 66.62 & 0.02 & 21.44 & 0.14 & 0.00 & 0.02 & 0.00 & 2.41 & 9.26 & 0.08 \\
\hline fsp & 3_4 & 66.64 & 0.02 & 21.42 & 0.16 & 0.00 & 0.04 & 0.02 & 2.56 & 9.10 & 0.04 \\
\hline fsp & 3_5 & 66.31 & 0.01 & 21.27 & 0.04 & 0.00 & 0.01 & 0.02 & 2.55 & 9.15 & 0.03 \\
\hline amph & 4_1 & 37.28 & 0.06 & 13.16 & 0.00 & 27.34 & 0.07 & 7.74 & 6.30 & 1.26 & 0.19 \\
\hline amph & 4_2 & 37.54 & 0.11 & 12.79 & 0.00 & 27.95 & 0.07 & 7.62 & 6.53 & 1.38 & 0.17 \\
\hline amph & 4_3 & 37.84 & 0.08 & 12.78 & 0.00 & 27.32 & 0.15 & 7.85 & 6.45 & 1.33 & 0.16 \\
\hline amph & 4_4 & 37.61 & 0.03 & 13.18 & 0.00 & 28.28 & 0.10 & 7.70 & 6.28 & 1.40 & 0.16 \\
\hline amph & $4 \_5$ & 37.72 & 0.07 & 12.97 & 0.00 & 27.82 & 0.17 & 7.74 & 6.33 & 1.32 & 0.20 \\
\hline fsp & 5_1 & 63.35 & 0.02 & 20.37 & 0.17 & 0.00 & 0.04 & 0.01 & 2.34 & 7.59 & 0.05 \\
\hline fsp & 5_2 & 63.75 & 0.02 & 20.49 & 0.11 & 0.00 & 0.04 & 0.02 & 2.38 & 6.98 & 0.06 \\
\hline fsp & 5_3 & 63.46 & 0.02 & 20.71 & 0.12 & 0.00 & 0.02 & 0.01 & 2.42 & 6.61 & 0.03 \\
\hline fsp & 5_4 & 63.92 & 0.00 & 20.39 & 0.09 & 0.00 & 0.00 & 0.00 & 2.43 & 6.03 & 0.04 \\
\hline fsp & 5_5 & 64.89 & 0.09 & 20.61 & 0.18 & 0.00 & 0.01 & 0.01 & 2.35 & 5.43 & 0.07 \\
\hline fsp & 5_6 & 65.12 & 0.04 & 20.83 & 0.18 & 0.00 & 0.00 & 0.01 & 2.43 & 4.82 & 0.05 \\
\hline fsp & 5_7 & 65.74 & 0.04 & 21.99 & 0.40 & 0.00 & 0.02 & 0.01 & 3.34 & 6.04 & 0.05 \\
\hline fsp & 5_8 & 66.21 & 0.01 & 22.26 & 0.46 & 0.00 & 0.03 & 0.00 & 3.39 & 5.25 & 0.05 \\
\hline fsp & 5_9 & 66.20 & 0.02 & 22.33 & 0.32 & 0.00 & 0.02 & 0.00 & 3.35 & 4.69 & 0.01 \\
\hline fsp & 5_10 & 66.23 & 0.01 & 22.11 & 0.30 & 0.00 & 0.03 & 0.00 & 3.38 & 4.52 & 0.05 \\
\hline g & 7_1 & 38.57 & 0.06 & 21.19 & 0.00 & 28.94 & 0.37 & 2.67 & 11.62 & 0.01 & 0.00 \\
\hline g & $7 \_2$ & 39.17 & 0.02 & 21.80 & 0.00 & 29.76 & 0.71 & 2.43 & 10.71 & 0.01 & 0.02 \\
\hline g & 7_3 & 38.28 & 0.05 & 21.08 & 0.00 & 29.93 & 0.71 & 2.57 & 10.74 & 0.04 & 0.00 \\
\hline g & 7_5 & 48.84 & 0.01 & 16.27 & 0.00 & 23.39 & 1.35 & 0.11 & 6.95 & 0.00 & 0.00 \\
\hline g & 9_6 & 47.83 & 0.01 & 17.78 & 0.00 & 24.83 & 1.12 & 0.13 & 7.77 & 0.01 & 0.02 \\
\hline
\end{tabular}




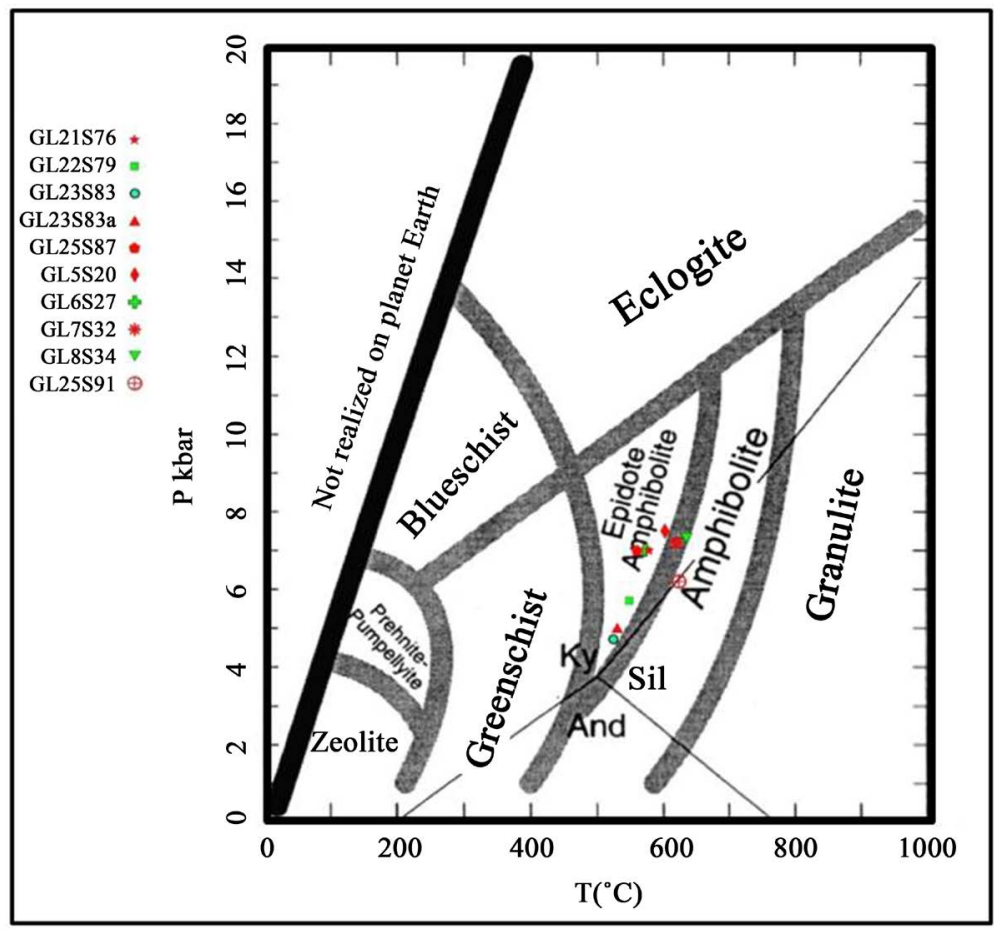

Figure 20. Diagram showing main metamorphic facies, tri-points of $\mathrm{Al}_{2} \mathrm{O}_{3}$, and thermo barometric study of samples [14].

calculation using garnet, plagioclase and amphibole minerals points to temperature of $580^{\circ} \mathrm{C}$ and pressure of 7 kilo bar for metamorphic condition of garnet-amphibolites (Figure 20).

\section{Conclusions}

Based on the facts and findings, it can be concluded that Gelmandeh complex is the result of metamorphosis of rocks within a shallow basin, which is accompanied by magmatic rocks as they all place atop an ultrabasic to basic basement. Gelmandeh complex was originally a complex of arenite-quartz sandstones with intercalations of shallow basin limestones.

Geochemical studies imply that the basement of the basin is of gabbro or basalt with calc-alkaline to alkaline nature, which originated from an enriched mantle origin. These studies show their formation environment was of continental type, which probably might be the sign for a hotspot deep in the mantle.

This complex along with mafic intrusive and extrusive rocks at its lower part was probably metamorphosed 547 million years ago (metamorphic age of amphibolites in Gelmandeh) that was concurrent with the penetration of basic to intermediate complexes with composition of gabbro-diorite. Total rock geochemical studies on samples of amphibolites confirm the aforementioned assumption to some extent. Such studies point to two separable origins for amphibolites, and divide them into two complexes; one is of calc-alkaline to alkaline nature with enriched mantle origin $\left(\mathrm{Eu} / \mathrm{Eu}^{*}>1\right)$ and the other is of calc-alkaline to tholeiitic or crustal contaminated nature $\left(\mathrm{Eu} / \mathrm{Eu}^{*}<1\right)$. Both complexes formed in a continental tectonic setting. Such results make one think of two different origins or one origin in two different times originated from a hotspot, which indicate the former was directly originated from the mantle and is older, and the latter is younger but underwent crustal contamination.

During the course of this metamorphism, quartzites turned to mica schist, limestones to marbles, and the basement and basic intrusive to amphibolites. The results from mineral assemblage in petrographic studies and the results from microprobe electron analysis point to metamorphism as high as amphibolite facies.

The presence of hornblende bands with CHERMAKIT and HASTINGZIT composition along with high content of epidote in amphibolites indicates to epidote-amphibolite facies, and presence of large garnets with almandine composition implies to facies transition to the higher grade. Barometric studies on samples taken from the studied area point to metamorphism of BAROVIAN type and epidote-amphibolite metamorphic facies with 
precedence of maximum pressure peak over maximum temperature peak. The calculation yields an average temperature of $580^{\circ} \mathrm{C}$ and pressure of 7 kilo bar.

\section{References}

[1] Haghipour, A., Pelissier, G., Bolourchi, M.H., Valeh, N., Aghanabati, A., Davoudzadeh, M., Stocklin, J., Sluiter, W. and Huber, H. (1970) Geological Map of Ardakan (1/250000). Iranian Geological Survey.

[2] Babakhani, A.R. and Majidi, J. (1995) Geological Map of Saghand (1/100000). Iranian Geological Survey.

[3] Ramezani, J. and Tucker, R.D. (2003) The Saghand Region, Central IRAN: U-Pb Geochronology, Petrogensis and Implication for Gondwana Tectonics. American Journal of Science, 303, 622-665. http://dx.doi.org/10.2475/ajs.303.7.622

[4] Ramezani, J. (1997) Regional Geology, Geochronology and Geochemistry of the Igneous and Metamorphic Rock Suites of the Saghand Area, Central IRAN. Ph.D. Thesis, Washington University, St. Louis, Missouri, 416.

[5] De la Roche, H., Leterrier, J., Grandclaude, P. and Marchal, M. (1980) A Classification of Volcanic and Plutonic Rocks Using R1-R2 Diagrams and Major Element Analyses-Its Relationships with Current Nomenclature. Chemical Geology, 29, 183-210. http://dx.doi.org/10.1016/0009-2541(80)90020-0

[6] Pearce, J.A. (1996) A User’s Guide to Basalt Discrimination Diagrams. In: Wyman, D.A., Ed., Trace Element Geochemistry of Volcanic Rocks: Applications for Massive Sulphide Exploration, Geological Association of Canada, Short Course Notes, Vol. 12, 79-113.

[7] Hastie, A.R. Kerr, A.C. Pearce, J.A. and Mitchell, S.F. (2007) Classification of Altered Volcanic Island Arc Rocks Using Immobile Trace Elements: Development of the Th-Co Discrimination Diagram. Journal of Petrology, 48, 2341-2357. http://dx.doi.org/10.1093/petrology/egm062

[8] Irvin, T.N. and Baragar, W.R.A. (1971) A Guide to the Chemical Classification of the Common Volcanic Rocks. Canadian Journal of Earth Sciences, 8, 523-548. http://dx.doi.org/10.1139/e71-055

[9] Thompson, A.B. (1982) Dehydration Melting of Politic Rocks and the Generation of $\mathrm{H}_{2} \mathrm{O}$-Undersaturated Granitic Liquids. American Journal of Science, 282, 1567-1595. http://dx.doi.org/10.2475/ajs.282.10.1567

[10] Wood, D.A. (1980) The Application of a Th-Hf-Ta Diagram to Problems of Tectonomagmatic Classification and to Establishing the Nature of Crustal Contamination of Basaltic Lavas of the British Tertiary Volcanic Province. Earth and Planetary Science Letters, 50, 11-30. http://dx.doi.org/10.1016/0012-821X(80)90116-8

[11] Harker, A. (1909) The Natural History of Igneous Rocks. Methuen \& Co., London.

[12] Spear, F. (2005) Metamorphic Phase Equilibria and Pressure-Temperature-Time Paths. Department of Earth and Environmental Sciences Rensselaer, Polytechnic Institute Troy, New York, Mineralogical Society of America, Washington DC.

[13] Apted, M.J. and Liou, J.G. (1983) Phase Relations among Greenschist, Epidote-Amphibolite and Amphibolite in a Basaltic System. American Journal of Science, 283, 328-354.

[14] Holdaway, M.J. (1971) Stability of Andalusite and the Aluminosilicate Phase Diagram. American Journal of Science, 271, 97-l3l. http://dx.doi.org/10.2475/ajs.271.2.97

\section{Submit or recommend next manuscript to SCIRP and we will provide best service for you:}

Accepting pre-submission inquiries through Email, Facebook, LinkedIn, Twitter, etc.

A wide selection of journals (inclusive of 9 subjects, more than 200 journals)

Providing 24-hour high-quality service

User-friendly online submission system

Fair and swift peer-review system

Efficient typesetting and proofreading procedure

Display of the result of downloads and visits, as well as the number of cited articles

Maximum dissemination of your research work

Submit your manuscript at: http://papersubmission.scirp.org/ 